\title{
The Effectiveness of Blended-Based Training on Teachers Competence in Padang Lawas District
}

\author{
Albert Efendi Pohan ${ }^{{ }^{*}}$, Pandhit Isbianti ${ }^{2}$ \\ 'Faculty of Education, Universitas Riau Kepulauan \\ ${ }^{2}$ Faculty of Education, Universitas Negeri Yogyakarta \\ * Author Correspondence. E-mail1: albertefendi.2020@student.uny.ac.id, Telp.+6282288851853 \\ Received: 12 August 2021; Revised: 02 September 2021; Accepted: 25 October 2021
}

\begin{abstract}
This study aims to determine the effectiveness of blended-based training on improving the teachers competence to act their main roles in preparing appropriate learning administration. The research was conducted in Padang Lawas Regency North Sumatra. To achieve the objective, preexperimental research by one-group pre-test and post-test design was adopted. Research subjects were from teachers in Padang Lawas District with 31 teachers. The instrument which was used was a portfolio and individual test by writing the lesson plan and all tasks collected by google drive. The data analysis technique was performed using SPSS Statistic 20 by one simple paired t-test. The finding showed that blended-based training had a significant difference of values where the post-test score was bigger than the pre-test score where the significant value (2-tailed) was $0.00<0.05$ could improve the teachers' professionalism. Thus, blended training can improve teacher professionalism in Padang Lawas District.
\end{abstract}

Keywords: blended-based training, professionalism, teacher

How to Cite: Pohan, A.E. \& Pandhit, I. (2021). The Effectiveness of Blended-Based Training on Teachers Competence in Padang Lawas District. JPPM (Jurnal Pendidikan dan Pemberdayaan Masyarakat), 8(2), 186-195. doi: 10.21831/jppm.v8i2.43092

\section{Introduction}

Teachers, as one component of education, play a critical part in education's implementation, as they are tasked with duties such as establishing collaborative lesson plans (Gutierrez, 2020), developing competence, potential and skills of students (Stemberger, 2020), and measuring progress of students' learning (De Simone, 2020). As a result, teachers must be highly competent in order to perform their tasks professionally. According to Abusomwan and Osaigbovo (2020), teacher competence entails the methods, strategies, and techniques used by teachers in the teaching process, such as effective classroom management, motivating skills, teaching methods, evaluation strategies, lesson plan preparation, and effective use of teaching materials. Furthermore, Olohundare (2020) asserts that competent teachers should be more dedicated to their work on a regular basis by preparing for lesson administration, entering the classroom at the appropriate time, ensuring that students have a better understanding of the material being taught, and taking detailed notes on student progress. students and pay close attention to the obstacles that impede them from learning effectively. Furthermore, professional teachers must be able to manage classes effectively so that they can create supportive environments for directing and regulating students' social behavior (Omenka and Otor, 2015). 
Previous empirical research has established that teacher competence in Indonesia is in urgent need of improvement (Siswandari, 2013; Lestari and Purwanti, 2018; Rohmat, 2019). This is because the teachers become one of the determinants of educational success, but still lack competence (Dwirahayu et al., 2020) and is also an external factor (Dahar 2011; Syarifuddin, 2011) that affects the implementation of education, in addition to factors relating to the students themselves and subject matter mastery (Dahar, 2011). Additionally to mastering the material necessary to transfer knowledge, teachers must master competencies in the areas of research, curriculum mastery, development of instructional materials, lifelong learning, sociocultural competence, emotional competence, communication skills, ICT mastery, adaptation to their teaching environment (Selvi, 2010; Olga, 2012; Dwirahayu, et al. 2020), mastery of classroom management, mastery of assessment methods, and problem solving skills (Selvi, 2010; Olga, 2012; Dwira (Peklaj, 2015). However, the reality on the ground reveal that teacher competency is still poor and teachers are unable to achieve the ideal described above (Maulipaksi, 2016; Yuliana, 2020). This is evidenced by the low national score for the Teacher Competency Test, which is 5.7. (Kemendikbud, 2020).

Yuliana's research (2019) has revealed that the primary and current problems facing teachers are related to learning tools that are created solely for the purpose of meeting administrative requirements; there are still teachers who are unable to develop the syllabus for learning tools independently, and teachers who prepare learning tools do not do so based on the required competencies. will be accomplished. This predicament is a result of insufficient teacher preparation in Indonesia, particularly in the most rural, poor, and outermost regions due to geographical constraints (Lantip, et al 2017). The primary issue is that the training is not implemented in accordance with the outcomes of past training evaluations. The trainings are limited to major city centers. This is consistent with the author's interview with on March 14, 2021, which revealed that out of 45 instructors, none have ever received training to improve teacher competency in relation to the policy of independent learning and/or modifications to the prior curriculum.

According to the data above, the cause of low teacher competency in the country's most remote, impoverished, and frontier regions is a lack of equal distribution of training (Pohan, et al., 2021). As a result, the researcher believes that it is vital to provide training for teachers in remote, impoverished, and frontier areas in order to enhance their teaching abilities. Regular training can help teachers increase their expertise. Participating in training has been shown to improve teacher knowledge, teacher competence, and teacher performance. (Graha, 2005), (Novitasari et al., 2012), (Baharuddin et al., 2013), (Wiguna, 2015), (Trijanuar, 2016), (Sulistyo, et.al., 2016), (Julianry, et.al., 2017), (Slameto et.al., 2017), (Kahpi et.al., 2017), (Husnah et.al., 2018), (Qomariah, 2020), and (Pohan, et.al., 2021).

The training model employed in this study was Blended-Based Training in the District of Padang Lawas. This training approach was selected in response to the Covid19 conditions, which compelled all countries to work diligently to discover solutions that would allow the education process to take place (Rahayu and Wirza, 2020). Another reason is that stringent lockdowns, particularly those in educational institutions, have been implemented in Indonesia and other nations (Syauqi, Munandi, \& Triyono, 2020; Napitupulu, 2020). Blended training combines online and face-to-face instruction. Blended training is a type of training that blends face-to-face instruction with online 
learning activities (Hidayat, et.al., 2020; Ahmad, et.al., 2020; Ningsih, et.al., 2017). Blended training can help individuals enhance their self-regulation, which will ultimately result in more effective and efficient results (Usman, 2019). This is consistent with study published by (Abdullah, 2018), which indicates that the blended training model can enhance learning and training effectiveness.

According to Whicadee (2017), blended training is an excellent technique to improve results since it may help participants develop abilities through active involvement in online classroom communities. Additionally, this research demonstrated that blended training can improve teachers' content relevance and involvement across several modalities of learning. Through the use of technology, the training will increase collective knowledge and equip participants with web-based applications for work outside of training. Additionally, Subaidi et al. (2019) demonstrated that blended training can improve teacher competence. This is because the application can assist teachers in a practical manner during the training process. Training enables flexibility, as it can be conducted in a non-face-to-face context. Subsequent research by Sudjana et al. (2019) demonstrated that blended training can improve learning effectiveness, reach, time and cost efficiency, and ultimate outcomes.

According to the Law of the Republic of Indonesia No. 14 of 2005 on Teachers and Lecturers, competence is a collection of knowledge, abilities, and behaviors that a teacher or lecturer must possess, internalize, and regulate in order to perform his professional tasks. Competence refers to an individual's ability to carry out his/her primary responsibilities effectively and in accordance with his/her field (Qomariah, 2020). This is consistent with Sunyoto's (2015) assertion that competence is the ability to perform tasks pertaining to one's field and expertise. Thus, teacher competency can be defined as a teacher's capacity to carry out his/her primary responsibilities in accordance with his/her area of knowledge. According to Law No. 20 of 2003, the primary responsibilities of teachers are to develop lesson plans, give instruction, and evaluate learning results. The purpose of this study is to provide targeted training to teachers in order to increase their competence in developing lesson plans and/or administering learning in accordance with the notion of independent learning, specifically a one-sheet lesson plan.

\section{Method}

Pre-experimental research was used in this study. According to Sugiyono (2019), experimental research is a quantitative technique for determining the effect of an independent variable (treatment) on a dependent variable (outcome) under controlled settings. Meanwhile, the researchers employed a one-group pretest-posttest design for this pre-experimental research. This type of research was conducted on a single set of individuals by administering a pre-test, conducting treatment, and then administering a post-test to determine the effect of treatment by comparing the pre-test and post-test values. The chart below provides an overview of this type of research. 


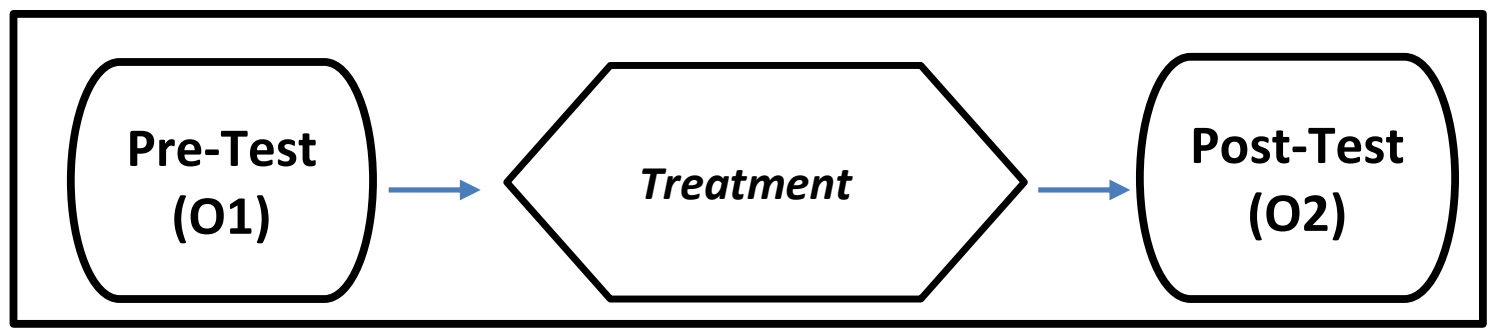

Chart 1. One-group pretest-posttest design by Sugiyono (2019)

The study was carried out in Padang Lawas District, North Sumatra Province, at the Computer Laboratory of SMA Negeri 1 Barumun Tengah, which is located at Jalan. KH. Council No. 15 Binanga Market. The research was conducted in partnership with the Gunung Tua District Education Office Branch in North Sumatra Province from February to June of the Second Term of the 2020-2021 Academic Year. The subjects of this study were selected teachers, both civil servants and non-permanent teachers, totaling 31 teachers. The first technique for collecting data as a pre-test score prior to treatment is through a portfolio assessment of the teacher's lesson plans. Following that, the researchers conducted blended training, which included both online and face-to-face instruction, for six meetings using the Zoom meeting platform. Following that, the researcher collected secondary data to be utilized as post-test scores on the assignment in order to create a lesson plan. The results of this project were thoroughly evaluated using a previously defined rubric.The results of this study were processed using statistical programs 21 to determine the homogeneity and normality, test the hypotheses, as well as to present the results in the form of tables and graphs. If the posttest value $\left(\mathrm{O}_{2}\right)$ is greater than the pre-test value $\left(\mathrm{O}_{1}\right)$, the hypothesis is accepted. This indicates that blended-based training can help teachers enhance their ability to develop lesson plans.

\section{Research Findings}

\section{Result and Discussion}

The findings of this study were the resulys of evaluating the lesson plans prepared by instructors in Padang Lawas Regency, North Sumatra during the Second Term of the 2020-2021 Academic Year, both before and after treatment was given. The following table summarizes the research findings.

Table 1. Results of Pre-Test and Post-Test

\begin{tabular}{lcc}
\hline \multirow{2}{*}{ Indicators } & \multicolumn{2}{c}{ Results } \\
\cline { 2 - 3 } & Pre-Test & Post-Test \\
\hline Total Score & 1956 & 2430 \\
Average & 63.10 & 78.39 \\
Score & & \\
Highest & 78 & 90 \\
Score & & \\
Lowest Score & 50 & 55 \\
Median & 64 & 80 \\
Mode & 64 & 80 \\
\hline
\end{tabular}


Table 1 above provides the intial description of the teacher's capacity to design lessons based on teacher scores on the pre- and post-tests, with an average pre-test score of 63.10 and a post-test score of 78.39. Additionally, the table above describes the profile of the teacher's capacity to prepare lesson plans, with the lowest teacher score on the pre-test being 50 and the highest teacher score on the post-test being 55. Additionally, the highest teacher score on the pre-test is 78 , while the highest teacher score on the post-test is 9o. According to the assessment provisions, teachers who are declared competent in the preparation of lesson plans must get a minimum of 70 points. The chart below illustrates the percentage of teachers who are capable of developing lesson plans.

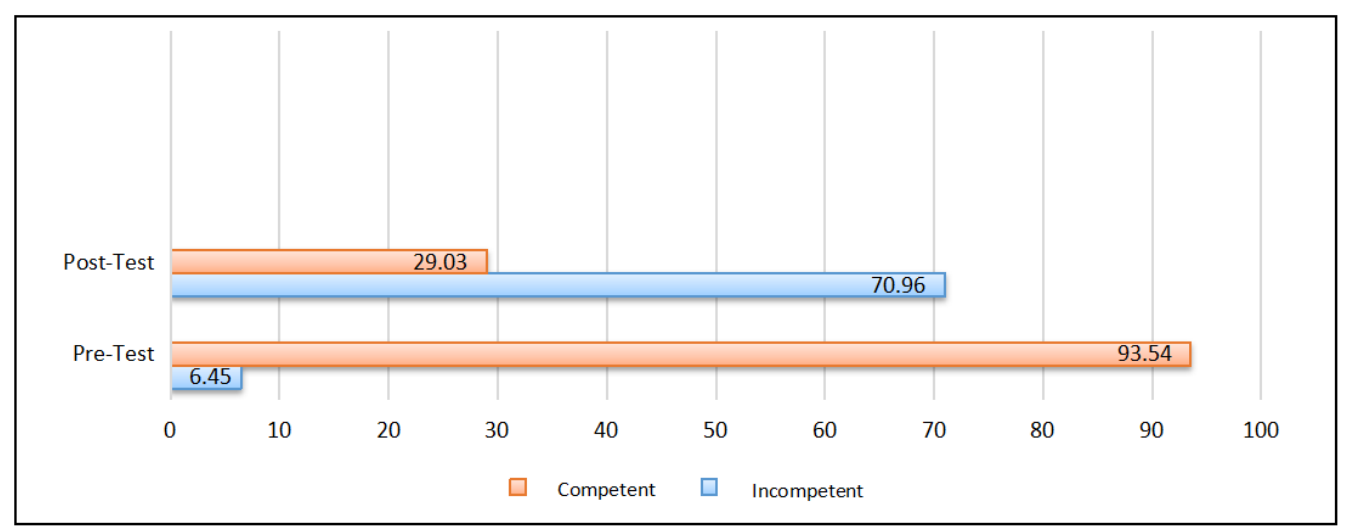

Diagram 1. Comparison of Teachers' Competence in the Pre-Test and Post-Test

\section{Test of Normality}

This normality test was conducted using SPSS analysis and the KolmogorovSimirnov One-Sample Test. If the significance value (Sig.) is greater than 0.05 , the research data is considered to be regularly distributed. Meanwhile, if the significance level (Sig.) is less than 0.05 , the data in the study are not normally distributed. The findings of the One-Sample Kolmogorov-Simirnov Test for Normality are shown below.

Table 2. Results of the Normality Test using One-Sample Kolmogorov-Simirnov Test

\begin{tabular}{llr}
\hline & & \multicolumn{2}{c}{$\begin{array}{c}\text { Unstandardized } \\
\text { Residual }\end{array}$} \\
$\mathrm{N}$ & & 31 \\
Normal Parameters & Mean & oE-7 \\
& Std. & 4.72991779 \\
Most Extreme & Deviation & \\
Differences & Absolute & .110 \\
& Positive & .110 \\
Kolmogorov-Smirnov Z & Negative & -.074 \\
Asymp. Sig. (2-tailed) & & .611 \\
\hline
\end{tabular}

As shown in Table 2, the results of the normality test using the One-Sample Kolmogorov-Simirnov Test were normal. The significance value was found to be 0.849 $>0.05$, indicating that the residual value was normally distributed. 


\section{Testing the Hypotheses}

The Paired Simple t-test was performed to examine whether blended training can increase teacher competency in Padang Lawas Regency. If the significance value (2tailed) is less than 0.05 , then there is a significant difference between the pre- and posttest values. Additionally, if the significance value (2-tailed) is greater than 0.05 , there is no significant difference between the pre- and post-test values. The following table summarizes the results of the hypothesis testing.

Table 3. Results of Hypotheses Testing Using Paired Simple t-test

\begin{tabular}{|c|c|c|c|c|c|c|c|c|c|}
\hline & & \multicolumn{5}{|c|}{ Paired Differences } & \multirow[t]{2}{*}{$\mathrm{t}$} & \multirow[t]{2}{*}{$\mathrm{df}$} & \multirow{2}{*}{$\begin{array}{c}\text { Sig. } \\
(2- \\
\text { tailed) }\end{array}$} \\
\hline & & Mean & $\begin{array}{c}\text { Std. } \\
\text { Deviation }\end{array}$ & $\begin{array}{c}\text { Std. } \\
\text { Error } \\
\text { Mea } \\
\text { n }\end{array}$ & $\begin{array}{l}\text { Lowe } \\
\mathrm{r}\end{array}$ & Upper & & & \\
\hline Pair & Variable & - & 5.001 & .898 & - & - & - & 30 & .000 \\
\hline 1 & $\begin{array}{l}\mathrm{O}_{1}- \\
\text { Variable } \\
\mathrm{O}_{2}\end{array}$ & $\begin{array}{r}15.29 \\
0\end{array}$ & & & 17.125 & 13.456 & $\begin{array}{r}17.02 \\
2\end{array}$ & & \\
\hline
\end{tabular}

According to the hypothesis test results in Table 3, a significant difference exists between the pre- and post-test scores of teachers in Padang Lawas Regency who participated in blended training. This is demonstrated by the Paired Simple t-test findings, which show a significance value (2-tailed) of 0.00 , which is less than 0.05 . According to the conclusions above, blended training has an effect on improving teacher competency in the Second Term of the 2020-2021 Academic Year in Padang Lawas District.

\section{Discussion}

The objective of this study is to determine the effect of blended training through pre-experimental research. The hypothesis test results indicate that this combined training can help teachers in Padang Lawas Regency increase their competency. The competence in this situation refers to the teacher's capacity to create a one-sheet lesson plan that adheres to the provisions of the independent learning program. Professional teachers must be able to complete administration for teaching and learning (Gutierez, 2020) and then apply it to develop student competence (Stemberger, 2020) and measure the progress of student learning (De Simone, 2020). There are various reasons why blended training can help improve teacher competency in Padang Lawas Regency, including teacher collaboration, schedule flexibility, face-to-face online communication, and trainee enthusiasm.

According to one of the school principals, notably the Head of SMA Negeri 1 Barumun Tengah in Padang Lawas Regency, the instructors at that school have never engaged in this type of training, let alone under Covid-19 conditions. This scenario requires teachers to conduct all school activities from their own residences, preventing teachers from collaborating effectively to conduct conversations and share experiences. Teachers may collaborate actively in this blended training environment, where they can learn more effectively and efficiently from one another. This is consistent with Saovapa Wichadee's position (2017). Teachers who complete this training will be able to create single-sheet lesson plans using digital collaboration, which will include the development 
of learning objectives, the development of learning activities, and the assessment of learning outcomes (Kemendikbud, 2019).

This blended training has allowed teachers to receive instruction from the comfort of their own homes, both online and via the zoom meeting application. This training mode can assist teachers in the process of teaching and learning as it also provides applicable methods for teaching. This type of training allows for greater flexibility, as it may be conducted without face-to-face interaction yet still maintains a high level of participant engagement (Subaidi, et al., 2019). After finishing the course, teachers can review the materials by re-watching the available recordings. Teachers can easily and effectively enhance training materials at any moment. This is consistent with the findings of Sudjana et al. (2019), which suggest that mixed-methods training can improve learning effectiveness, reach, time and cost efficiency, and final outcomes.

Blended training is extremely beneficial for teachers in terms of mastering the training material because it enables teachers to communicate easily in order to resolve issues and face challenges in teaching. Teachers can communicate effectively both within and outside of the online classroom. This is consistent with the assertion of Tubagus et al. (2019), which suggests that blended training enables trainees to improve communication skills both in and out of the classroom through online interactions with one another to discuss common difficulties and can optimize learning by enhancing learning independence. Through this training, teachers can learn how to collaborate successfully to complete training activities. Developing one-sheet lesson plans is still a novel concept for teachers in Padang Lawas Regency, as they had never receieved the opportunity to attend training. However, through this training, they could develop the lesson plan both independently and collaboratively.

Indeed, blended training can create environments that teachers have never encountered as trainees. As a result, this circumstance has an effect on the trainees' degree of enthusiasm. Not only does blended training provide a learning experience, but it also creates a positive and supportive learning atmosphere. This is consistent with research findings (Wai and Seng, 2014; Tubagus, et al., 2019). As a result, teacher competency development in the form of blended training is the most appropriate option during the Covid-19 pandemic season for increasing effectiveness, efficiency, and more attractiveness in connecting with individuals in varied learning contexts. This approach enables students to study independently and concurrently and at different times, ensuring that the Covid-19 epidemic does not become an impediment to learning.

\section{Conclusion}

According to the discussion above, the findings of this study indicate that the blended training conducted by researchers can assist teachers in Padang Lawas District, North Sumatra improve their competence, particularly their ability to develop a onesheet lesson plan that adheres to the concept of an independent learning curriculum. Hypothesis testing using the paired simple t-test indicates a significance value (2tailed) of 0.00 , which is less than 0.05 . Thus, when the post-test value is greater than the pre-test value, there is a significant difference in teachers' competence following the provision of blended training.

Based on the conclusions above, the authors can make the following recommendations to researchers, teachers, and school principals: 
1) Implementing blended training to improve teacher competence in making learning preparations, particularly in the current era of the Covid-19 pandemic;

2) Conducting research with different or identical variables to improve teacher competence in developing lesson plans, teaching, and conducting learning assessments.

3) Conducting research in other undeveloped parts of Indonesia using different or identical variables in order to increase teacher competency in developing lesson plans, teaching, and conducting learning assessments;

4) Providing similar training to teachers in Indonesia's outermost, underdeveloped, and remote areas in order to increase teacher competency in preparing for, administering, and assessing learning.

5) Ensure the effectiveness of learning by monitoring the results and implementation of training at schools in Indonesia's outermost, underdeveloped, and remote areas.

\section{References}

Abdullah, W. (2018). Model Blended Learning dalam Meningkatkan Efektifitas Pembelajaran. Jurnal Fikrotuna, Volume 7(1), 855-866.

Agus Subaidi, Moh Zayyadi, Hasanah. I. S, dan Durroh Halim. (2017). Pelatihan Blended Learning bagi Guru Di Lingkungan Madrasah Tsanawiyah Negeri Sumber Bungur. JPPM (Jurnal Pemberdayaan Masyarakat), Volume 4(2), 2019.

Ahmad, Perwira Negara, H. R., Ibrahim, M., \& Etmy, D. (2020). Pelatihan Pembelajaran Daring (Google Classroom) bagi Guru MTs dan MI Nurul Yaqin Kelanjur. JPMB : Jurnal Pemberdayaan Masyarakat Berkarakter, Volume 3(1), 66-79.

Baharuddin, A., Alhabsyi, T., \& Utami, H. N. (2013). Pengaruh Pelatihan, Kompensasi Dan Disiplin Kerja Terhadap Prestasi Kerja Karyawan (Studi Pada Kantor PT. PLN (Persero) Area Pelayanan dan Jaringan Malang). Jurnal Profit, Volume 6(2), 56-68.

Dahar, R.W. (2011). Teori-Teori Belajar dan Pembelajaran. Jakarta: Erlangga.

Dwirahayu, G., Satriawati, G., Afidah., \& Hafiz, M. (2020). Analysis Of Mathematics Teachers' Pedagogical Competency In Madrasah Tsanawiyah In Developing Scientific-Based Lesson Plan. Jurnal Pendidikan dan Kebudayaan, Volume 5(1), Juni 2020.

Graha, A. N. (2005). Pengaruh Pelatihan Terhadap Kemampuan Karyawan Dan Dampaknya Terhadap Kinerja Karyawan (Studi Pada Karyawan PT. Gatra Mapan Malang). Modernisasi, 1(2), 75-93.

Hidayat.M.T., Teuku Junaidi., \& Effendi. D.I. (202). Pelatihan Blended Learning Melalui Aplikasi Mobile Bagi Guru SMP pada Masa Pandemi Covid-19. International Journal of Community Service Learning, Volume 4(3) 200-208.

Husnah, L., Setyowati, T., \& S, W. E. (2018). Pengaruh Pelatihan Kerja, Lingkungan Kerja Dan Komitmen Organisasi Terhadap Kinerja Karyawan Di Royal Hotel Jember. Jurnal manajemen dan bisnis indonesia, Volume 4(1), 33-45.

J.J. De Simone. (2020). The Roles of Collaborative Professional Development, SelfEfficacy, and Positive Affect in Encouraging Educator Data Use to Aid Student Learning, Teacher Development. An International Journal of Teachers' Professional Development.

Julianry, A., Syarief, R., \& Affandi, M. J. (2017). Pengaruh Pelatihan dan Motivasi Terhadap Kinerja Karyawan serta Kinerja Organisasi Kementerian Komunikasi dan Informatika. Jurnal Aplikasi Bisnis dan Manajemen, Volume 3(2), 236-245. 
JPPM (Jurnal Pendidikan dan Pemberdayaan Masyarakat), 8 (2), 2021 - 194

Albert Efendi Pohan, Pandhit Isbianti

K.A. Omenka dan E.E. Otor. (2015). Influence of Classroom Management on Students' Academic Achievement in Science and Mathematics in Oju Local Government Area of Benue State. Global Journal of Interdisciplinary Social Science, volume 4(4), 36-40.

Kahpi, H. S., Khurosaini, A., \& Indra, S. (2017). Pengaruh Pelatihan dan Motivasi Berprestasi Terhadap Kinerja Pegawai Dengan Kompetensi Sebagai Variabel Intervening. Jurnal Riset Bisnis dan Manajemen Tirtayasa (JRBMT), Volume 1(1), 110.

Lantip, D.P., Wibowo, U.D., \& Arum, D.H. (2017). Curriculum Management Of Teacher Professional Program For Frontier, Outermost, And Least Developed Regions In Universitas Negeri Yogyakarta. Jurnal Pendidikan dan Kebudayaan, Volume. 2(1), 2017.

Lestari, Y.A. \& Purwanti, M. (2018). Hubungan Kompetensi Pedagogik, Profesional, Sosial, dan Kepribadian Pada Guru Sekolah Nonformal X. Jurnal Kependidikan, Volume 2(1), 197-208.

Lia Yuliana. (2019). Achievement Of National Education Standards In Senior Secondary Schools. Jurnal Pendidikan dan Kebudayaan, Volume 4(2), 2019.

Maulipaksi, D. (2016). Tujuh Provinsi Uji Kompetensi Guru 2015. https://s.id/wP 3 Nw dikases pada hari Minggu, o3 Januari 2021 Pukul 3.30 Wib

Napitupulu, Rodame Monitorir. (2020). Dampak Pandemi Covid-19 Terhadap Kepuasan Pembelajaran Jarak Jauh. Jurnal Inovasi Teknologi Pendidikan, Volume 7(1): 23-33.

Ningsih, Y. L., Misdalina, M., \& Marhamah, M. (2017). Peningkatan Hasil Belajar dan Kemandirian Belajar Metode Statistika Melalui Pembelajaran Blended Learning. AlJabar: Jurnal Pendidikan Matematika, Volume 8 (2), 155-167.

Novitasari, A., Wahyudin, A., \& Setiyan, R. (2012). Pengaruh Kepemimpinan Kepala Sekolah, Lingkungan Kerja, Pendidikan, Dan Pelatihan Terhadap Kinerja Guru. Economic Education Analysis Journal, Volume 1(2).

Olga N. (2012). The Competencies of the Modern Teacher. Paper presented at the Annual Meeting of the Bulgarian Comparative Education Society $\left(10^{\text {th }}\right.$, Kyustendil, Bulgaria, Jun 12-15, 2012). https://files.eric.ed.gov/fulltext/ED567059.pdf.

Peklaj, C. (2015). Teacher Competencies Through the Prism of Educational Research. Center for Educational Policy Studies Journal, Volume 5(3), 183-204.

Peraturan Kementerian Pendidikan dan Kebudayaan Republik Indonesia Nomor 22 Tahun 2020 Tentang Rencana Strategi Kementerian Pendidikan dan Kebudayaan

Qomariah, N \& Mustikawati, E. (2020). The Effect of Education, Training and Competency on Teacher Performance. International Journal of Business and Management Invention (IJBMI), Volume 9(10), 14-20.

Rahayu, Retno Puji, and Yanty Wirza. (2020). Teachers' Perception of Online Learning during Pandemic Covid-19. Jurnal Penelitian Pendidikan Volume 20(2) 392-406.

Rohmat Sulistiya. (2019). Heutagogy As A Training Approach For Teachers In The Era Of Industrial Revolution 4.o. Jurnal Pendidikan dan Kebudayaan, Volume 4(2), 2019.

Sally B. Gutierez. (2020). Collaborative Lesson Planning as a Positive 'Dissonance' to the Teachers' Individual Planning Practices: Characterizing the Features Through Reflections-On-Action, Teacher Development. An International Journal of Teachers' Professional Development. 
Saovapa Wichadee. (2017). A Development of the Blended Learning Model Using Edmodo for Maximizing Students' Oral Proficiency and Motivation. International Journal of Emerging Technologies in Learning, Volume 12(2), 2017.

Selvi, K. (2010). Teachers' Competencies. Cultura. International Journal of Philosophy of Culture and Axiology, Volume 7(1), 167-175.

Siswandari dan Susilaningsih. (2013). Dampak Sertifikasi Guru Terhadap Peningkatan Kualitas Pembelajaran Peserta Didik. Jurnal Pendidikan dan Kebudayaan, Volume $19(4), 487-498$.

Slameto, Sulasmono, B. S., \& Wardani, K. W. (2017). Peningkatan Kinerja Guru Melalui Pelatihan Beserta Faktor Penentunya. Jurnal Pendidikan Ilmu Sosial, Volume 27(2), $38-47$.

Sugiyono, Sugiyono. (2019). Metode Penelitian Manajemen Pendekatan Kuantitatif, Kualitatif, Kombinasi (Mixed Method), Penelitian Tindakan (Action Research), Dan Penelitian Evaluasi. In Book Chapter, ed. Setiyawan. Bandung: Alfabeta.

Sujana, I. M., Waluyo, U., Soepriyanti, H., dan Arifuddin. (2019). Workshop Pengembangan Blended learning Berbasis Google Classroom (GC) sebagai Solusi Pembelajaran dan Penelitian Tindakan Kelas (PTK). Jurnal Pendidikan dan Pengabdian Masyarakat, Volume 2(1), 2019.

Sulistyo, B., Minarsih, M. M., \& Warso, M. M. (2016). Pengaruh Pendidikan Dan Latihan Profesi Guru ( PLPG), Kedisiplinan Guru, Dan Kompetensi Guru Terhadap Kinerja. Journal of Management, Volume 2(2), 2016.

Olohundare, S. K. (2020). Assessment of Teachers' Dedication, Discipline, Knowledge and Skills in Kwara State Basic Schools, Nigeria. Journal of Education and Learning (EduLearn), Volume 14(4), 537-542.

Abusomwan, S. B \& Osaigbovo, L. (2020). Competency Improvement Needs of Teachers of Brick/Block Laying and Concreting Works. Journal of Education and Learning (EduLearn), Volume 14(4), 517-524.

Sunyoto, D. (2015). Penelitian Sumber Daya Manusia. PT. Buku Seru Unggul

Syarifuddin, A. (2011). Penerapan Model Pembelajaran Cooperative Belajar dan FaktorFaktor yang Mempengaruhinya. Ta'dib: Journal of Islamic Education (Jurnal Pendidikan Islam), Volume 16(1), 113-136.

Syauqi., Khusni, Munadi, S., \& Triyono, M. B. (2020). Students' Perceptions toward Vocational Education on Online Learning during the Covid-19 Pandemic. International Journal of Evaluation and Research in Education, Volume 9(4): 881-86.

Stemberger, T. (2020). The Teacher Career Cycle and Initial Motivation: The Case of Slovenian Secondary School Teachers, Teacher Development. An International Journal of Teachers' Professional Development, Volume 24(5), 709-726.

Tubagus, M., Muslim, S. \& Suriani. (2019). The Impact of the Development of Blended Learning Models Using Computer Applications In Higher Education. International Journal of Educational Research Review, Volume 4(4), 573-581.

Usman, U. (2019). Komunikasi Pendidikan Berbasis Blended Learning Dalam Membentuk Kemandirian Belajar. Jurnal Jurnalisa, Volume 4(1), 136-150.

Wai, C. C., \& Seng, E. L. K. (2014). Exploring the Effectiveness and Efficiency of Blended Learning Tools in a School of Business. Procedia-Social and Behavioral Sciences, Volume 1(23), 470-476.

Wiguna, I. D. G. E. C. (2015). j Dewa Gede Eka Candra Wiguna, I. (2015). Pengaruh Gaya Kepemimpinan, Komunikasi. E-Jurnal Manajemen Unud, Volume 4(9), 2527-2543 